Benjamin Lasshof

Operating Costs of Real Estate 


\section{Schriftenreihe Bauökonomie}

herausgegeben von

Prof. Dr. Christian Stoy

\section{Band 5}




\section{Benjamin Lasshof}

\section{Operating Costs of Real Estate}

Models and Cost Indicators for a Holistic Cost Planning 
Dissertation, Universität Stuttgart (D 93), 2017

ISBN 978-3-11-059514-7

e-ISBN (PDF) 978-3-11-059608-3

e-ISBN (EPUB) 978-3-11-059616-8

Library of Congress Control Number: 2018934294

Bibliografische Information der Deutschen Nationalbibliothek

Die Deutsche Nationalbibliothek verzeichnet diese Publikation in der Deutschen Nationalbibliografie; detaillierte bibliografische Daten sind im Internet über http://dnb.dnb.de abrufbar.

(C) 2018 Walter de Gruyter GmbH, Berlin/Boston

Druck und Bindung: $\mathrm{CPI}$ books $\mathrm{GmbH}$, Leck

@) Gedruckt auf säurefreiem Papier

Printed in Germany

www.degruyter.com 